\title{
Pengembangan Perangkat Pembelajaran Matematika dengan Menggunakan Model Pembelajaran Berbasis Masalah
}

\author{
Zakiyah Anwar $^{1}$, R. Ruslan ${ }^{2}$ \\ Pendidikan Matematika FKIP UM Sorong, Pendidikan Bhs. Inggris FKIP UM Sorong \\ e-mail: ${ }^{1}$ zakiyahanwar@um-sorong.ac.id, ${ }^{2}$ ruslanruse@gmail.com
}

\begin{abstract}
Abstrak
Penelitian ini adalah penelitian pengembangan dengan ujicoba terbatas yang bertujuan untuk mengembangkan perangkat pembelajaran dengan Penerapan model pembelajaran berbasis masalah pada pokok bahasan Sistem Persamaan Linear dan Kuadrat yang terdiri dari Buku Siswa, Lembar Kegiatan Siswa, dan Rencana Pelaksanaan Pembelajaran. Subjek Penelitian ini adalah siswa SMA Al Amin Kota Sorong. Prosedur pengembangan yang digunakan dalam penelitian ini adalah model Thiagarajan atau model 4D (Define, Design, Develop, dan Disseminate) yang meliputi empat tahap, yaitu tahap pembatasan, tahap perancangan, tahap pengembangan, dan tahap penyebaran. Hasil dari Validasi instrument dari dua validator menunjukkan perangkat pembelajaran memiliki derajat validitas dan layak untuk di gunakan. Hasil uji coba terbatas perangkat pembelajaran dengan menggunakan model pembelajaran berbasis masalah efektif dan praktis dengan perolehan skor rata-rata hasil tes belajar siswa adalah 82,17 dari skor ideal 100 dengan standar deviasi 10,34. dengan perangkat pembelajaran dengan penerapan model pembelajaran berbasis masalah, siswa jadi lebih aktif dalam proses pembelajaran; pada umumnya siswa memberikan respon yang positif terhadap perangkat pembelajaran, tingkat kemampuan guru dalam mengelola proses pembelajaran dengan menggunakan model pembelajaran berbasis masalah termasuk dalam kategori tinggi, artinya penampilan guru dapat dipertahankan. Penelitian ini sangat penting untuk terus dikembangkan agar dalam pembelajaran di kelas siswa dapat belajar lebih aktif dan efektif.
\end{abstract}

Kata kunci: Model Pembelajaran; Perangkat Pembelajaran; berbasis masalah

\begin{abstract}
This research is development research with limited trials aimed at developing learning tools by applying problem-based learning models to the subject of the Linear and Quadratic Equation System consisting of Student Books, Student Activity Sheets, and Learning Implementation Plans. The subjects of this study were Al Amin Sorong City High School students. The development procedure used in this study is the Thiagarajan model or the 4D model. The results of the instrument validation from the two validators show the learning device has a degree of validity and is suitable for use. The results of limited trials of learning devices using effective and practical problem-based learning models with the acquisition of an average score of student learning test results is 82.17 of the ideal score of 100 with a standard deviation of 10.34. with learning tools with the application of problem based learning models, students are more active in the learning process; students give a positive response to the learning device, the level of the teacher's ability to manage the learning process by applying problem-based learning models included in the high category, the application of teacher performance can be maintained. This research is very important to continue to be developed so that in learning in the classroom students can learn more actively and effectively.
\end{abstract}

Keywords: Learning model; Learning Media; problem based 


\section{PENDAHULUAN}

Pengembangan pembelajaran matematika dengan menggunakan pembelajaran matematika berbasis masalah merupakan salah satu cara melatih daya nalar, berpikir secara kritis dan sistematis bagi siswa sehingga siswa akan memiliki pemahaman konsep matematika yang baik.

Sebagai tenaga pengajar/pendidik guru memegang peranan penting yang sangat vital dalam menentukan peningkatan dan perbaikan kualitas pembelajaran yang akan dicapai siswanya. Pembelajaran yang selama ini adalah pembelajaran yang berbasis konvensional, yaitu pembelajaran yang berpusat pada guru. Belajar akan lebih bermakna bagi siswa jika anak mengalami sendiri apa yang dipelajarinya dengan baik. Pembelajaran yang berorientasi target penguasaan materi hanya menanamkan kompetensi mengingat jangka pendek, tetapi gagal dalam membekali anak memecahkan persoalan dalam kehidupan jangka panjang. Hal itulah yang terjadi di kelas-kelas sekolah kita. Dilihat pada konteks yang mengarah pada perbaikan kualitas pendidikan, maka pembelajaran berbasis masalah merupakan salah satu pendekatan pembelajaran yang dapat dipergunakan dalam memperbaiki sistem pembelajaran. Tidak bisa di pungkiri selama ini kemampuan siswa untuk menyelesaikan masalah kurang diperhatikan oleh guru. Akibatnya ketika siswa menghadapi suatu masalah, walaupun masalah itu dianggap mudah untuk di selesaikan, banyak juga siswa yang tidak dapat menyelesaikannya dengan baik.

Salah satu model pembelajaran yang dapat digunakan yang sejalan dengan hakikat matematika adalah model pembelajaran basis masalah (Problem Based Learning). [6] sebagai pakar PBL (Problem Based Learning) menyatakan bahwa defenisi PBL adalah sebagai sebuah metode pembelajaran yang didasarkan pada prinsip bahwa masalah (problem) dapat digunakan sebagai titik awal untuk mendapatkan ataupun mengintegrasikan ilmu (knowledge) baru. Landasan teori PBL adalah Kolaboratif, suatu perspektif yang berpendapat jika siswa menyusun sendiri pengetahuannya dengan cara membangun penalaran dari pengetahuan yang sudah dimiliki dan dari semua yang diperoleh sebagai hasil kegiatan berinteraksi dengan sesama individu.

\section{Rumusan Masalah}

Rumusan masalah dalam penelitian ini Bagaimana hasil pengembangan perangkat pembelajaran matematika dengan menggunakan model berbasis masalah (problem based learning) pada siswa kelas X SMA Muhammadiyah Al Amin Kota Sorong. 


\section{Tujuan Penelitian}

Tujuan dari penelitian ini adalah untuk menghasilkan perangkat pembelajaran matematika yang valid, efektif dan praktis dengan menggunakan model pembelajaran berbasis masalah (problem based learning). Perangkat pembelajaran yang akan dikembangkan adalah: Buku Siswa (BS), Lembar Kegiatan Siswa (LKS), Rencana Pelaksanaan Pembelajaran (RPP), Tes Hasil Belajar (THB)

\section{METODE PENELITIAN}

\section{Jenis Penelitian}

Jenis penelitian ini adalah penelitian pengembangan (Research and Development) meliputi pengembangan perangkat pembelajaran, yang terdiri dari Buku Siswa, Rencana Pelaksanaan Pembelajaran (RPP), Lembar Kerja Siswa dan Tes Hasil Belajar (THB).

\section{Lokasi dan Subjek Penelitian}

Uji coba perangkat pembelajaran dalam penelitian ini dilaksanakan di SMA Al Amin Muhammadiyah Kota Sorong dan subjek penelitiannya adalah siswa Kelas X

\section{Prosedur Penelitian}

Penelitian ini akan dilaksanakan pada Semester Berjalan Tahun Pelajaran 2019/2020 yang melalui tiga tahap yaitu.

1. Tahap Persiapan

Kegiatan yang dilakukan pada kegiatan ini adalah:

1) Menelaah kurikulum.

2) Mengembangkan perangkat pembelajaran terdiri dari buku siswa, lembar kegiatan siswa, rencana pelaksanaan pembelajaran, dan tes hasil belajar siswa.

3) Membuat lembar observasi untuk mengamati aktivitas siswa, aktivitas guru dan pengelolaan pembelajaran di kelas.

4) Mempersiapkan angket untuk mengetahui respon siswa dan guru mengenai perangkat pembelajaran yang dikembangkan.

2. Tahap Pelaksanaan

Pada tahap ini kegiatan yang dilakukan adalah:

1) Membagi kelompok berdasarkan kemampuan siswa siswa. 
2) Melaksanakan pembelajaran matematika dengan menggunakan model pembelajaran berbasis masalah (problem based learning).

3) Selama proses pembelajaran dilakukan pengamatan berupa aktivitas siswa dan guru, serta kemampuan guru mengelola pembelajaran.

\section{Tahap Analisis Data}

Kegiatan pada tahap ini adalah menganalisis data yang diperoleh dari tahap pelaksanaan. data yang akan dianalisis merupakan data hasil belajar siswa, data hasil pengamatan aktivitas siswa dan aktivitas guru, dan data hasil pengamatan pengelolaan pembelajaran.

\section{Pengembangan Perangkat Pembelajaran Matematika}

Pengembangan perangkat pembelajaran matematika mengacu pada model 4-D Thiagarajan. yaitu Pendefenisian, Perancangan, Pengembangan dan Penyebaran.

Berikut adalah uraian secara rinci tahap-tahap pengembangan model 4-D yang dilakukan dalam penelitian ini.

1. Tahap Pendefenisian

Tujuannya adalah menetapkan dan menentukan syarat-syarat pembelajaran yang meliputi tujuan pembelajaran, dan pembatasan materi pembelajaran. Adapun langkah-langkahnya sebagai berikut:
a. Analisis Kurikulum
b. Analisis Karakteristik Siswa
c. Analisis Konsep
d. Analisis Tugas
e. Spesifikasi Tujuan Pembelajaran

2. Tahap Perancangan

Pada tahap ini, akan dihasilkan rancangan perangkat pembelajaran dan tes hasil belajar siswa. Langkah-langkah dalam tahap ini adalah:
a. Penyusunan Tes
b. Pemilihan Media
c. Pemilihan Format 


\section{Rancangan Awal}

Tahap ini merupakan Rancangan awal perangkat pembelajaran materi sistem persamaan linear. Adapun rancangan awal perangkat pembelajaran tersebut meliputi Buku Siswa, Lembar Kegiatan Siswa (LKS), Rencana Pelaksanaan Pembelajaran (RPP), dan Tes Hasil Belajar (THB). Semua perangkat pembelajaran yang dihasilkan pada tahap ini disebut dengan perangkat pembelajaran draft I.

3. Tahap Pengembangan

Tahap pengembangan bertujuan mendapatkan draft dari perangkat pembelajaran yang telah direvisi berdasarkan masukan para ahli dan data yang diperoleh dari ujicoba. Kegiatan yang dilakukan pada tahap ini adalah validasi perangkat pembelajaran dan ujicoba terbatas.

a. Penilaian Para Ahli

Perangkat pembelajaran draft I yang telah dihasilkan pada tahap perancangan, setelah validator memberikan masukan atau saran, untuk penyempurnaan draft I. Perangkat pembelajaran yang telah direvisi berdasarkan penilaian para ahli maka akan diperoleh perangkat pembelajaran draft II.

\section{b. Ujicoba Terbatas}

Ujicoba yang ini bersifat terbatas yaitu hanya dilakukan satu kali terbatas pada satu kelas. Kegiatan ini untuk mendapatkan masukan atau saran dari siswa dan guru di lapangan dalam rangka untuk merevisi perangkat pembelajaran draft II. Rangkaian kegiatan ujicoba terdiri dari dua tahap, yaitu pelaksanaan proses pembelajaran dan tes akhir setelah ujicoba selesai, selanjutnya dilakukan revisi berdasarkan data hasil ujicoba. Sebagai hasilnya maka diperoleh perangkat pembelajaran yaitu draft III.

4. Tahap Penyebaran

Tahap penyebaran belum dapat dilakukan karena penelitian ini digunakan untuk keperluan terbatas dengan waktu yang cukup singkat. Tahap penyebaran dapat dilakukan apabila pengembangan perangkat digunakan pada skala yang lebih luas.

\section{Instrumen Pengumpulan Data}

Instrumen pengumpul data dalam penelitian ini adalah Tes Hasil Belajar, observasi serta angket. Angket ditunjukkan kepada siswa dan guru, untuk mengetahui pendapatnya terhadap materi pelajaran, perangkat pembelajaran yang digunakan serta untuk mengetahui minat siswa 
dan guru dalam pembelajaran dengan menggunakan model pembelajaran berbasis masalah. Adapun instrumen pengumpulan data yang digunakan dalam penelitian ini adalah sebagai berikut:

1. Lembar pengamatan aktivitas siswa

2. Lembar Pengamatan Aktivitas Guru

3. Lembar pengamatan pengelolaan pembelajaran matematika menggunakan model pembelajaran berbasis masalah (PBL)

4. Respon siswa terhadap kegiatan pembelajaran

5. Respon guru terhadap perangkat pembelajaran yang digunakan

6. Tes Hasil Belajar

\section{Teknik Analisis Data}

Berikut ini dikemukakan tentang analisis data keshahihan, kepraktisan dan keefektifan dari perangkat pembelajaran yang telah dikembangkan.

1. Analisis data keshahihan perangkat pembelajaran dengan model pembelajaran berbasis masalah Adapun kegiatan yang dilakukan dalam proses analisis data keshahihan model pembelajaran berbasis masalah menurut Nurdin (2007:142) adalah:

a. Melakukan rekapitulasi hasil penilaian validator ke dalam tabel yang meliputi Bidang Telaah $\left(A_{i}\right)$, Indikator $\left(K_{i}\right)$ dan hasil penilaian validator $\left(V_{j i}\right)$

b. Mencari rerata hasil penilaian ahli untuk setiap indikator $\left(\overline{K_{i}}\right)$ dengan rumus:

$$
\begin{aligned}
& \overline{K_{i}}=\frac{\sum_{j=1}^{n} V_{i j}}{n} \text {, dengan } \quad \text { (Nurdin, 2007: 142) } \\
& \bar{K}_{i}=\text { rerata kriteria ke-i } \\
& V_{j i}=\text { skor hasil penilaian terhadap indikator ke-i bidang telaah ke-j } \\
& n=\text { banyaknya indikator dalam telaah ke-i }
\end{aligned}
$$

c. Mencari rata-rata untuk setiap bidang telaah $\left(A_{i}\right)$ dengan rumus: 


$$
\begin{gathered}
\bar{A}=\frac{\sum_{j=1}^{n} \bar{K}_{i j}}{n} \text {, dengan (Nurdin dalam Nurhawa , 2015: 8) } \\
\overline{K_{i j}}=\text { rata-rata indikator ke-i bidang telaah ke-j } \\
n=\text { banyaknya indikator dalam telaah ke-i }
\end{gathered}
$$

d. Mencari rata-rata total $(\bar{X})$ dengan rumus

$$
\begin{aligned}
& \bar{X}=\frac{\sum_{i=1}^{n} \overline{A_{i}}}{n}, \text { dengan } \\
& \overline{A_{i}}=\text { rata-rata aspek ke-i } \\
& n=\text { banyaknya aspek }
\end{aligned}
$$

e. Menentukan kategori validitas setiap indikator atau bidang telaah dengan mencocokkan rerata indikator $\left(\overline{K_{i}}\right)$, rata-rata bidang telaah $\left(A_{i}\right)$ maupun rata-rata total $(\bar{X})_{\text {dengan kategori }}$ validitas yang ditetapkan.

f. Rerata Validitas perangkat setiap indikator secara keseluruhan ditetapkan sebagai berikut:

$3,5 \leq \mathrm{M} \leq 4,0 \quad$ kategori sangat valid (SV)

$2,5 \leq \mathrm{M}<3,5 \quad$ kategori valid $(\mathrm{V})$

$1,5 \leq \mathrm{M}<2,5 \quad$ kategori cukup valid $(\mathrm{CV})$

$\mathrm{M}<1,5 \quad$ kategori tidak valid (TV)

Apabila seluruh aspek tidak berada pada kategori kategori valid maka perlu dilakukan revisi berdasarkan saran para validator atau dengan melihat kembali aspek-aspek yang nilainya kurang. Selanjutnya dilakukan validasi ulang lalu dianalisis kembali sampai memenuhi kriteria Valid..

2. Analisis data keefektifan perangkat pembelajaran dengan model pembelajaran berbasis masalah Analisis data keefektifan perangkat pembelajaran dengan model pembelajaran berbasis masalah didukung oleh hasil analisis data dari 5 komponen keefektifan, yaitu: (1) hasil belajar siswa atau ketuntasan klasikal, (2) aktivitas siswa, (3) respon siswa, (4) aktivitas guru, (5) pengelolaan 
pembelajaran oleh guru. Oleh karena itu, kegiatan analisis data terhadap kelima komponen itu adalah sebagai berikut:

1. Analisis Data Hasil Belajar Siswa

Analisis dilakukan terhadap skor-skor yang diperoleh siswa dari Tes Hasil Belajar yang diberikan setelah semua materi tuntas dibahas. Kriteria yang digunakan untuk menentukan skor adalah skala lima berdasarkan teknik kategorisasi standar yang ditetapkan oleh Departemen Pendidikan Nasional (DEPDIKNAS, 2003), adalah:

1. Kemampuan $85 \%-100 \%$ atau skor $85-100$ (kategori sangat tinggi)

2. Kemampuan $65 \%-84 \%$ atau skor $65-84$ (kategori tinggi)

3. Kemampuan $45 \%$ - $64 \%$ atau skor 45-64 (kategori sedang)

4. Kemampuan $35 \%-44 \%$ atau skor 35-44 (kategori rendah)

5. Kemampuan 0\% - 34\% atau skor 0-34 (kategori sangat rendah)

2. Analisis Data Aktivitas Siswa

Data hasil observasi aktivitas siswa selama kerjasama dalam kelompok dilaksanakan dianalisis dan dideskripsikan. Untuk mencari rata-rata persentase waktu yang digunakan siswa melakukan aktivitas selama kerjasama dalam kelompok.

3. Analisis Data Aktivitas Guru

Data hasil observasi guru selama kerjasama dalam kelompok dilaksanakan dianalisis dan dideskripsikan. Untuk mencari rata-rata frekuensi dan rata-rata persentase waktu yang digunakan guru selama aktivitas siswa bekerjasama dalam kelompok.

4. Analisis Respon Siswa

Kegiatan yang dilakukan untuk menganalisis data respon siswa terhadap perangkat pembelajaran dengan model pembelajaran berbasis masalah. Adapun analisis untuk menghitung persentase peserta didik dengan memberikan respon pada setisp kategori yang ditanyakan dalam lembar angket 


\section{Analisis Data Kepraktisan Perangkat Pembelajaran Matematika dengan Model Pembelajaran Berbasis Masalah}

Untuk mengamati kepraktisan pembelajaran berbasis masalah, maka dilaksanakan pembelajaran dengan fase PBL dan menggunakan perangkat pembelajaran berbasis masalah. Data kepraktisan model diperoleh dari hasil pengamatan keterlaksanaan model (pengelolaan pembelajaran) secara umum dari seorang pengamat.

Kriteria yang digunakan untuk memutuskan bahwa model pembelajaran memiliki keterlaksanaan yang memadai adalah nilai $\left(A_{i}\right)$ dan $(\bar{X})$ minimal berada dalam kategori “Tinggi” berarti penampilan guru dapat dipertahankan. Apabila berada pada kategori rendah, maka guru harus mampu meningkatkan kemampuannya dengan melihat kembali aspek-aspek yang nilainya kurang.

\section{HASIL DAN PEMBAHASAN}

Hasil Pengembangan Perangkat Pembelajaran

Pengembangan perangkat pembelajaran matematika dengan menggunakan model pembelajaran berbasis masalah berdasarkan Model 4D yaitu

1. Tahap Pembatasan (Define) diantaranya yaitu Telaah Kurikulum, Analisis siswa, Analisis konsep, Analisis tugas, Spesifikasi tujuan pembelajaran yang merupakan Perincian indikator pencapaian dan tujuan pembelajaran pada materi Sistem Persamaan Linear dan Kuadrat

\section{Tahap Perancangan (Design)}

Ditahap Perancangan berupa Penyusunan Tes, Pemilihan Media, Pemilihan Format, Rancangan Awal. Pada tahap ini dihasilkan perangkat pembelajaran, antara lain: Buku Siswa, Lembar Kerja Siswa dan Rencana Pembelajaran

Ketiga perangkat pembelajaran tersebut disebut draft 1.

\section{Tahap Pengembangan (Develop)}

Pada tahap ini dilakukan penilaian oleh para ahli untuk menelaah semua perangkat yang telah dihasilkan (Draft I). Penilaian berupa validasi isi, bahasa, dan kesesuaian perangkat pembelajaran dengan kurikulum yang berlaku. Hasil validasi dari para ahli digunakan sebagai 
dasar untuk melakukan revisi perangkat pembelajaran. perbaikan mengacu kepada saran-saran serta petunjuk dari para ahli.

\section{Ketercapaian tujuan penelitian}

\section{Kevalidan Perangkat Pembelajaran}

Hasil analisis perangkat pembelajaran buku siswa, LKS, RPP, Tes Hasil Belajar, nilai validasi disimpulkan perangkat-perangkat yang disebutkan di atas sudah termasuk dalam kategori "Valid' $(2,5 \leq \mathrm{M} \leq 3,5)$ dan Kedua ahli menyatakan bahwa perangkat pembelajaran yang dikembangkan dapat digunakan dengan revisi sedikit oleh karena itu dilakukan revisi berdasarkan saran kedua Ahli. Berdasarkan kriteria kevalidan maka perangkat pembelajaran telah memiliki derajat validitas dan layak untuk diujicobakan.

Analisis Deskriptif Hasil Penelitian

1. Hasil belajar siswa kelas X SMA Al Amin Muhammadiyah Sorong terhadap pelajaran matematika diperoleh skor rata-rata 82,17 dari skor ideal 100 dengan standar deviasi 10,34. Skor minimum yang diperoleh siswa adalah 55 dan skor maksimum yang diperoleh siswa adalah 95 dengan rentang skor 60 .

2. Data Hasil Pengamatan Aktivitas Siswa dan Aktivitas Guru

Hasil pengamatan untuk aktivitas siswa dan aktivitas guru selama proses pembelajaran berlangsung menunjukkan Hasil pengamatan aktivitas siswa dan aktivitas Guru diketahui semua kategori aktivitas siswa yang diamati memenuhi Interval Toleransi PWI (\%) yang ditentukan. Artinya, kriteria pencapaian waktu ideal aktivitas siswa terpenuhi.

3. Respons Siswa terhadap Kegiatan Pembelajaran dengan Menggunakan Model Pembelajaran Berbasis Masalah.

Respons siswa terhadap pelajaran matematika sangat bervariasi, ada respon siswa yang menyatakan bahwa matematika itu menyenangkan, sangat menantang hingga merasa bahwa matematika sangat sulit. Dari 18 siswa, 15 siswa (83,3\%) diantaranya merasa senang dengan pelajaran matematika. Mereka akan lebih senang lagi belajar matematika jika mereka berhasil memahami materi yang disajikan. Dari hasil observasi juga diketahui bahwa 3 dari 18 siswa $(16,67 \%)$ yang menyatakan bahwa matematika itu sangat sulit. Mereka mengatakan bahwa guru yang mengajar kurang memotivasi mempelajari matematika. Namun dengan adanya 
pembelajaran dengan menggunakan model pembelajaran berbasis masalah, mereka semakin menyukai pelajaran matematika karena matematika memiliki banyak tantangan/ masalah bagi mereka untuk diselesaikan.

4. Respons Siswa tentang Buku Siswa dan LKS

Respon siswa terhadap Buku Siswa dan LKS menyatakan bahwa 14 dari 18 siswa $(77,77 \%)$ merasa senang dengan buku siswa dan LKS yang digunakan. dengan LKS siswa lebih mudah mengerjakan soal matematika karena masalah yang disajikan memiliki langkahlangkah penyelesaian yang jawabannya dikosongkan, sehingga mereka bisa mengisi jawaban soal. dari 5 siswa $(27,7 \%)$ berpendapat bahwa ada beberapa contoh-contoh dalam buku siswa atau LKS terlalu sedikit dan tidak terlalu jelas serta masalah yang disajikan cenderung agak rumit dipahami.

5. Respons Siswa tentang Pembelajaran dengan Menggunakan model Pembelajaran Berbasis Masalah

Dari 18 siswa yang berada di kelas, 16 siswa $(88,8 \%)$ merasa senang dengan proses pembelajaran yang menggunakan model pembelajaran berbasis masalah, karena menurut mereka dengan model pembelajaran ini, memberikan suasana baru dalam proses belajar mereka dan mereka lebih banyak mengenal soal-soal matematika yang lebih menantang. Namun 2 siswa dari 18 siswa (11\%) tidak terlalu menyukai model pembelajaran berbasis masalah karena mereka merasa masalah yang disajikan sulit mereka pahami, disamping butuh pembiasaan terhadap model pembelajaran ini. 


\section{SIMPULAN}

Berdasarkan hasil analisis yang telah dilakukan dapat diambil kesimpulan sebagai berikut:

1) Perangkat pembelajaran matematika yang dikembangkan dengan model pembelajaran berbasis masalah pada pokok bahasan Sistem Persamaan Linear dan Kuadrat adalah Buku Siswa, LKS dan RPP.

2) Setelah dilakukan validasi dan revisi sebanyak 2 kali, perangkat pembelajaran yang meliputi Buku Siswa, LKS, dan RPP ini valid dan layak untuk digunakan berdasarkan hasil penilaian para ahli.

3) Pada umumnya siswa memberikan respons yang positif terhadap perangkat pembelajaran yang dikembangkan.

4) Dari hasil ujicoba diketahui bahwa perangkat pembelajaran dengan menggunakan model pembelajaran berbasis masalah bersifat efektif dan praktis, hasil ujicoba diuraikan sebagai berikut:

a. Skor rata-rata yang diperoleh siswa pada tes hasil belajar adalah 82,17 dari skor ideal 100 dengan standar deviasi 10,34. Dimana 18 dari 17 siswa atau 94,44\% memenuhi ketuntasan individu. Data ini menunjukkan bahwa ketuntasan klasikal tercapai.

b. perangkat pembelajaran dengan menggunakan model pembelajaran berbasis masalah, siswa menjadi lebih aktif dalam pembelajaran. terlihat dari terpenuhinya semua kategori aktivitas siswa yang diamati dengan memenuhi Interval Toleransi PWI (\%) yang ditentukan.

c. Dalam membimbing kelompok belajar terlihat dari 9 kategori aktivitas guru yang diamati, semua kategori tersebut terpenuhi dan memenuhi Interval Toleransi PWI (\%) yang ditentukan. 


\section{DAFTAR PUSTAKA}

Anwar, Z. (2017). Analisis Kesalahan Siswa dalam Menyelesaikan Masalah

Aljabar Siswa Kelas VII SMP Negeri 6 Kota Sorong. Jurnal Noken: Ilmu-Ilmu Sosial, 2(1), 1013.

, \& Arsyad, R. B. (2019). Profil Kemampuan Siswa SMP dalam Memecahkan Masalah Matematika Open-Ended Berdasarkan Kemampuan Prasyarat Tinggi. Qalam: Jurnal Ilmu Kependidikan, 7(2), 107-114.

Depdiknas, R. I. (2003). Departemen Pendidikan Nasional Republik Indonesia.

Fatmawati, Agustina. "Pengembangan Perangkat Pembelajaran Konsep Pencemaran Lingkungan Menggunakan Model Pembelajaran Berdasarkan Masalah untuk SMA Kelas X." Edu Sains: Jurnal Pendidikan Sains \& Matematika 4.2 (2016).

H.S. Barrows.. Problem Based Learning : A Research Perspective On Learning Interaction. Lawrence Erlbaum Associates. New York : Inc. Publishing Industrial Avenue. 1982

Murwaningsih, Utami, Erika Laras Astutiningtyas, and Nuryani Tri Rahayu. "Implementasi Pengembangan Perangkat Pembelajaran Matematika Realistik di Sekolah Menengah Pertama." Cakrawala Pendidikan .2014

Nurhawa, N. (2015). PENGEMBANGAN PERANGKAT PEMBELAJARAN BERBASIS MASALAH TERHADAP PENCAPAIAN MINAT DAN HASILBELAJAR FISIKA PESERTA DIDIK KELAS X SAINS SMA NEGERI 4 PINRANG (Doctoral dissertation, Univesitas Negeri Makassar).

Sulistyani, Niluh, and Heri Retnawati. "Pengembangan perangkat pembelajaran bangun ruang di SMP dengan pendekatan problem-based learning." Jurnal Riset Pendidikan Matematika 2.2 (2015): 197-210.

Nurdin. 2007. Model Pembelajaran Matematika yang Menumbuhkan Kemampuan Metakognisi untuk Menguasai Bahan Ajar. Disertasi Program Pascasarjana Program Studi Pendidikan Matematika Universitas Negeri Surabaya. Tidak diterbitkan.

Wena, M. 2012. Strategi Pembelajaran Inovatif Kontemporer suatu tinjauan Konseptual Operasional. Jakarta : Bumi Aksara 